Revta brasil. Bot., São Paulo, V.24, n.3, p.255-261, set. 2001

\title{
Pollination ecology of Tabebuia aurea (Manso) Benth. \& Hook. and T. ochracea (Cham.) Standl. (Bignoniaceae) in Central Brazil cerrado vegetation ${ }^{1}$
}

\author{
MARILUZA GRANJA BARROS ${ }^{2,3}$
}

(received: February 23, 2000; accepted: May 2, 2001)

\begin{abstract}
Pollination ecology of Tabebuia aurea (Manso) Benth. \& Hook. and T. ochracea (Cham.) Standl. in Central Brazil cerrado vegetation). The pollination ecology and breeding systems of Tabebuia aurea (Manso) Benth. \& Hook., and T. ochracea (Cham.) Standl. were investigated in an area of cerrado vegetation in the Federal District of Brazil. These species occur sympatrically, flower massively and synchronously for a month, during the dry season (July to September). Both have diurnal anthesis, with similar floral structures, a yellow tubular corolla and produce nectar. Fourteen species of bees visited both Tabebuia species, but, only three Centris species and Bombus morio, were considered potential pollinators, because of their high frequency on the flowers and their efficiency in carrying pollen. Tests on the breeding systems of T. aurea and T. ochracea demonstrated that boths species are self-incompatible, with late-acting self-incompatibility. The proportion of fruit set from cross pollination (T. aurea $17.2 \%$ and T. ochracea $12.3 \%$ ) in both species was low considering the great number of flowers displayed. This suggests a lack of maternal resources for fruit-set. The great amount of seeds per fruit (about 92 in T. aurea and 285 in T. ochracea) may represent an investment of maternal resources allocated on higher quality of fertilized ovules.
\end{abstract}

RESUMO - (Ecologia da polinização de Tabebuia aurea (Manso) Benth. \& Hook. e T. ochracea (Cham.) Standl. (Bignoniaceae) em cerrado do Brasil Central). Foram investigadas a ecologia da polinização e a biologia reprodutiva de Tabebuia aurea (Manso) Benth. \& Hook. e T. ochracea (Cham.) Standl. em uma área de cerrado em Brasília (DF) Brasil. Estas espécies ocorrem simpatricamente, florescem massiva e sincronicamente, por aproximadamente um mês, durante a estação seca (julho a setembro). Ambas espécies têm estruturas florais similares, antese diurna, corola tubular e são produtoras de néctar. Quatorze espécies de abelhas visitaram ambas Tabebuia, porém somente três espécies de Centris e Bombus morio foram consideradas polinizadores potenciais, devido a alta freqüência e à eficiência no transporte do pólen. Os testes de polinização artificial, demonstraram que T. aurea e T. ochracea são auto-incompatíveis, com auto-incompatibilidade de ação tardia. A proporção de frutos maturados resultantes de polinização cruzada foi baixa (T. aurea 17,2\% e T. ochracea 12,3\%) em ambas espécies, considerando o grande número de flores desabrochadas, sugerindo falta de recursos maternos. A grande quantidade de sementes por frutos (cerca de $92 \mathrm{em} T$. aurea e $285 \mathrm{em} \mathrm{T}$. ochracea) deve representar o investimento materno nos óvulos fertilizados que possuem maior vigor.

Key words - breeding systems, floral biology, synchrony of flowering

\section{Introduction}

Studies on the breeding systems of co-occuring plant species in the tropics which share pollinators, have attracted a great number of botanists and ecologists (Stiles 1975, Schemske 1981, Frankie et al. 1983, Armbruster 1986, Silberbauer-Gottsberger \& Gottsberger 1988, Saraiva et al. 1988, Vogel \& Machado 1991, Barros 1992, 1996, 1998, Oliveira \& Gibbs 1994, Proença \& Gibbs 1994), and may provide some clarification of the phylogeny and genetic trends of the flowering plants.

In the Bignoniaceae family, studies on the breeding systems and pollination revealed some

1. Parte da tese de doutorado de Mariluza Granja Barros.

2. Universidade de Brasília, Instituto de Ciências Biológicas, Departamento de Botânica, Caixa Postal 04457, 70919-970 Brasília, DF, Brasil.

3. Corresponding author: mabarros@unb.br insights of co-evolution with their pollen vectors as it was observed in Tabebuia chrysantha (Borrero 1972), Pachyptera hymenaea (Barrows 1977), Campsis radicans (Bertin 1982, 1985), Jacaranda caroba (Vieira et al. 1992), Pyrostegia venusta (Gobatto-Rodrigues \& Stort 1992) and Tabebuia caraiba (Gibbs \& Bianchi 1993). In this paper, pollination ecology and breeding systems of T. aurea and $T$. ochracea which occur sympatrically in the Brazilian cerrados are investigated.

\section{Material and methods}

The study was carried out in Brasília, Distrito Federal, in the cerrado the woodland savannas of Central Brazil (Eiten 1984). The fieldwork was conducted at Fazenda Água Limpa/ FAL $\left(15^{\circ} \mathrm{S}, 47^{\circ} 55^{\prime} \mathrm{W}\right)$, which is $28 \mathrm{~km}$ south of the University of Brasília. At FAL, Tabebuia aurea and T. ochracea are intermingled in open cerrado, but $T$. aurea is more frequent than $T$. ochracea (123 individuals for the first and 42 for the second). Fieldwork was undertaken from July to October during 1985/86 and some supplementary studies 
on phenological events were done in 1998/99. Eighty six individuals of $T$. aurea and twenty four of $T$. ochracea were monitored. Both species are trees or treelets $(1 \mathrm{~m}$ to $6 \mathrm{~m})$. Phenological observations were done weekly. Flowering individuals were noted at the beginning, the peak (when half of individuals are blooming), and the end of blooming period were registered.

Breeding systems were assessed by isolating flower buds in muslin bags just before anthesis. Hand self-pollination, automatic self-pollination (spontaneous), cross-pollination, interspecific pollination and apomixis, were performed. For the three latter treatments, flowers were emasculated before anthesis. As T. aurea and $T$. ochracea flowers have sensitive tactile stigmas, hand pollination was done by applying pollen on the tip of a flat dissecting needle onto the stigmatic arms. Some post-pollinated flowers were fixed in formalin acetic alcohol at 24:00 hr, 48:00 hr and 72:00 hr, for subsequent studies of development of the pollen tube using decolorized aniline blue and fluorescence microscopy (Martin 1959). Some flowers were tagged to investigate natural pollination and to compare their fruit production with those of the treatments.

Nectar volume were sampled from bagged flower with a $5 \mathrm{ml}$ capillary pipette and sugar concentration was measured with a pocket refractometer.

Pollination activities were monitored by visual observation and when possible bees were collected and identified. Patterns of visits number per minute (very frequent: about 36 , frequent: about 20 , rare: less than one) were established to characterize pollinator activities of the more frequent visitors.

\section{Results and Discussion}

Phenology - Tabebuia aurea and T. ochracea flowered massively for approximately one month during the dry season and had more than two weeks of synchronous flowering (figure 1). For both species, flowering peak occurs about one week after the beginning of flowering and they had some days of isolated flowering (T. aurea at the beginning, and $T$. ochracea at the end), as shown in figure 1 . The flowering pattern documented in $T$. aurea and $T$. ochracea was recognized by Gentry (1974a, b, c, 1976, 1992) among the Bignoniaceae of Central America. T. aurea and T. ochracea (figures 2-7) can be included in the cornucopian-type, with great number of flower displayed over several weeks. This seems to be a common pattern for Tabebuia, as it was noted by Frankie et al. (1983), in T. ochracea ssp. neochrysantha and by Bawa \& Webb (1984) in T. rosea. The floral convergence of $T$. aurea and $T$. ochracea blooming with a great number of flowers in leafless individuals (table 1), was assumed to be a strategy to increase floral density and visitors attraction. Synchronization of congeneric flowering species has been pointed out in many tropical plants and recently in Brazilian cerrado vegetation in
Byrsonima (Barros 1992), Diplusodon (Barros 1996), Erythroxylum (Barros 1998) and also in some Myrtaceae species (Proença \& Gibbs 1994). This seem to be a common pattern in mass-flowering plants, as suggested by Schemsky (1981), that synchronic flowering of congeneric may help to attract pollinators and increase pollen flow. However, this floral convergence and possible competition for pollination may increase interspecific pollen transfer and hybridization (Waser 1983).

Floral biology - The two Tabebuia have similar flowers arranged in condensed apical inflorescences, which are larger in T. aurea than in T. ochracea (table 1). The flowers are yellow, the corolla is infundibuliform

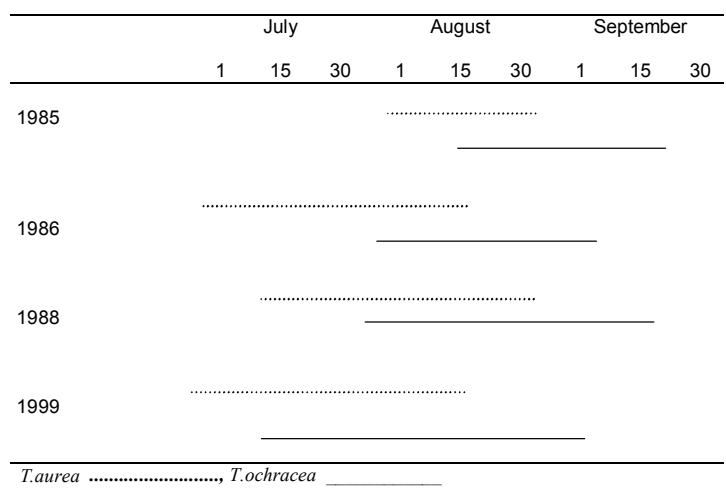

Figura 1. Flowering period of T. aurea (32 trees) and T. ochracea (21 trees)

Table 1. Floral morphology and nectar production pattern of the two Tabebuia species.

\begin{tabular}{lcc}
\hline & T. aurea & T. ochracea \\
\hline $\begin{array}{l}\text { Flower per individual }(\mathrm{n}=15) \\
\text { Inflorescence type }\end{array}$ & $\begin{array}{c}866 \\
\text { condensed } \\
\text { thyrsus } \\
12-156\end{array}$ & $\begin{array}{c}499 \\
\text { condensed } \\
\text { panicle }\end{array}$ \\
$\begin{array}{l}\text { Flowers per inflorescence } \\
\text { Calyx }\end{array}$ & $\begin{array}{c}\text { gabrous } \\
\text { faint perfume }\end{array}$ & $\begin{array}{c}\text { tomentose } \\
\text { vanilla perfume }\end{array}$ \\
Corola (inner) & absent & present \\
Nectar guide & $116-259$ & $196-503$ \\
Ovule number & $60-101$ & $153-364$ \\
Seed per fruit (n=5) & & \\
Nectar concentration $(\%)$ & $25.9 \%$ & $28.7 \%$ \\
$1^{\text {st }}$ day flowers & $27.0 \%$ & $30.6 \%$ \\
$2^{\text {nd }}$ day flowers & & \\
Nectart amount $(\mu 1)$ & $5.0 \mu 1$ & $4.0 \mu 1$ \\
$1^{\text {st }}$ day flowers & $3.2 \mu 1$ & $13 \mu 1$ \\
$2^{\text {nd }}$ day flowers &
\end{tabular}


5 - lobed (figure 2), with four didynamous stamens and a reduced staminode; the pistil, with linear ovary is located on the top of a nectariferous-disc, the style terminates in a bilabiate stigma which is sensitive and quickly closes after any touch. T. aurea, and $T$. ochracea have irregular diurnal anthesis $(7: 00 \mathrm{~h}$ to
16:00 h), being more frequent during the morning. At the beginning of anthesis the upper anthers dehisce, whilst the stigmatic-arms usually remain closed, opening about 30 minutes later, shortly followed by lower anthers. So, flowers are slightly protandrous and remain receptive for about one day. On the second
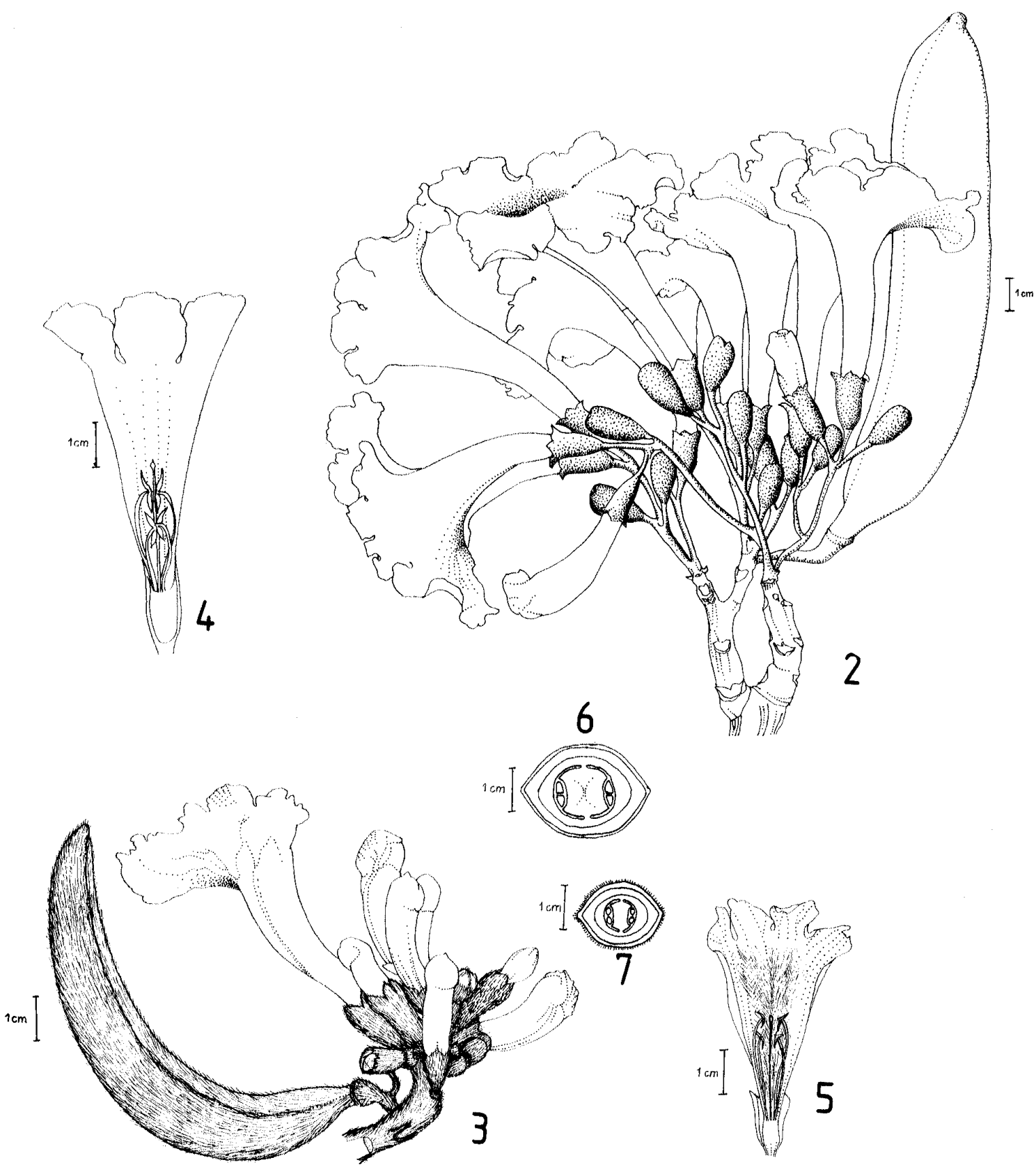

Figures 2-7. 2. Details of inflorescence and corolla of Tabebuia aurea. 3. Details of inflorescence and corolla of Tabebuia ochracea. 4. Longitudinal section of $T$. aurea flower. 5. Longitudinal section of $T$. ochracea flower. 6. Cross section of $T$. aurea ovary showing the nectary disk. 7. Cross section of T. ochracea ovary showing the nectary disk. (x1). 
Table 2. Fruit set following the treatments and natural pollination of $T$. aurea and $T$. ochracea $(\mathrm{n}=$ number of pollinated flowers, $\mathrm{f}=$ fruit).

\begin{tabular}{|c|c|c|c|c|c|c|}
\hline & \multicolumn{3}{|c|}{ T. aurea } & \multicolumn{3}{|c|}{ T. ochracea } \\
\hline & $\mathrm{n}$ & $\mathrm{f} \%$ & $\mathrm{n}$ & $\mathrm{f}$ & $\%$ & \\
\hline Self-pollination & 137 & - & - & 210 & - & - \\
\hline T. aurea & 97 & 15 & 15.5 & 127 & - & - \\
\hline T. ochracea & 73 & - & - & 119 & 26 & 21.8 \\
\hline Automatic pollination & 214 & - & - & 131 & - & - \\
\hline Apomixis & 71 & - & - & 108 & - & - \\
\hline Natural pollination & 209 & 36 & 17.2 & 259 & 32 & 12.3 \\
\hline
\end{tabular}

day, they become pale-yellow and the stigma turns brown. The corolla drops about five days after opening. The amount of nectar and its sugar concentration were similar in both Tabebuia species (table 1) with a maximum around 11:00 hr and decreasing from 16:30 $\mathrm{h}$ to the end of the afternoon.

The similar floral morphology and reward of $T$. aurea and $T$. ochracea suggest that these plants are involved in some kind of a floral mutualism. The striking similarities of congenerics, has been documented in some tropical plant species which share pollinators. This was registered by Schemsky (1981) on two species of Costus, by McDade (1985) on five species of Aphelandra, by Stucky (1985) on two species of Ipomoea and also by Frankie et al. (1983), who reported similar nectar values for some Tabebuia from Costa Rica.

Breeding systems - The results of controlled pollinations (table 2), show that $T$. aurea and $T$. ochracea set fruits only from intraspecific crosses. Both species matured very low number of fruits in comparison with the high number of displayed flowers. Most flowers dropped about five days after opening, without any sign of ovary enlargement. In both species, pollen tubes were observed entering ovules 24 hours after pollination but, no visible signs of fruits initiation occured up to ten days after pollination, and well after selfed pistils have dropped. In $T$. ochracea fruit set from natural pollination $(12.3 \%)$, was lower than from artificial cross pollination $(21.8 \%)$, but in $T$. aurea fruit set from natural pollination was higher $(17.2 \%)$, than from hand crosses $(15.5 \%)$.

Fluorescence microscopy showed no difference of pollen tube growth between crossed and selfed pistils, in either Tabebuia species. Selfing pollen tubes of both species, were observed entering ovules, suggesting late-acting self-incompatibility as shown
Table 3. Species of bees which visit flowers of the two species of Tabebuia. $(\mathrm{vf}=$ very frequent, $\mathrm{f}=$ frequent, $\mathrm{r}=$ rare).

\begin{tabular}{|c|c|c|}
\hline & T. aurea & T. ochracea \\
\hline \multicolumn{3}{|l|}{ ANTHOPHORIDAE } \\
\hline Centris albopilosa Moure* & vf & $\mathrm{f}$ \\
\hline C. discolor Smith & vf & $\mathrm{f}$ \\
\hline C. violacea (Lepeletier) & vf & vf \\
\hline Ceratina sp. & $\mathrm{f}$ & $\mathrm{f}$ \\
\hline Epicharis bicolor (Lepeletier) & $\mathrm{f}$ & $\mathrm{f}$ \\
\hline Exomalopsis sp. & $\mathrm{r}$ & $\mathrm{r}$ \\
\hline Hopliophora superba (Ducke) & $\mathrm{r}$ & $\mathrm{r}$ \\
\hline Tetrapedia rugulosa Friese & $\mathrm{r}$ & $\mathrm{r}$ \\
\hline \multicolumn{3}{|l|}{ APIDAE } \\
\hline Apis mellifera $\mathrm{L}$. & $\mathrm{f}$ & $\mathrm{f}$ \\
\hline Bombus morio (Swederus) & vf & $\mathrm{f}$ \\
\hline Euglossa melanotricha Moure & $\mathrm{f}$ & $\mathrm{r}$ \\
\hline Eulaema nigrita Lepeletier & $\mathrm{f}$ & $\mathrm{f}$ \\
\hline Trigona spinipes $(\mathrm{F})$ & vf & $\mathrm{f}$ \\
\hline \multicolumn{3}{|l|}{ HALICTIDAE } \\
\hline Augochloropsis sp. & vf & $\mathrm{f}$ \\
\hline
\end{tabular}

*identified, but not yet published.

in figure 3, (T. aurea). From interspecific crosses, it was observed a strong reaction with deposition of callose on the stigma and pollen tubes were blocked at the style base. Pistils from automatic pollinations, showed very few pollen tubes, while in natural pollination, many pollen tubes were detected reaching the ovules. This phenomenon was registered by Seavey \& Bawa (1986) in many tropical trees including Dipterix alata, which is a native cerrado tree. Since then it has been observed other Brazilian cerrado species, as Eriotheca gracilipes (Oliveira et al. 1992), Jacaranda caroba (Vieira et al. 1992), Chorisia chodattii, C. speciosa, Tabebuia 
caraiba (syn. T. aurea), T. ochracea (Gibbs \& Bianchi 1993), and Siphoneugena densiflora, Blepharocalyx salicifolius and Campomanesia velutina (Proença $\&$ Gibbs 1994). The late-acting self-incompatibility as observed in T. aurea and T. ochracea, seems to be a good strategy for the maternal parent selects best donors, as they had only one month of mass-flowering blooming, which may attract a great amount of pollinators. Late-acting self-incompatibility has been suggested to be advantageous by Stephenson \& Bertin (1983) and by Bawa \& Webb (1984), who argued that it will facilitate the quality control by a plant over the choice of mates and allocations of resources to the progeny. Since these plants produce large number of flowers in order to attract visitors, it would be easier the best developing pistilis than to control the kind of pollen tube arriving to ovaries (Seavey \& Bawa 1986). Gibbs \& Bianchi (1993), studying the same Tabebuia species, could not find any clear differences in early embriology of selfed ovules, and they were unable to define if self-sterility in the species was reality a self-incompatibility process similar to "classic" incompatibility.

Fruit set - The low pattern of fruit set in both Tabebuia, for cross polination (artificial) and natural pollination, shown in table 1 , seem unlikely to be caused by lack of pollination, as these plants were massively (artificial) pollinated or abundantly visited by pollinators. It was assumed here that the availability of resources, rather than the number of pollinated flowers, determine of the upper limit to fruit production. In some individuals of T. aurea, which produced more than five hundred flowers, it was observed only one or two fruits (pers. observation). This suggests that in both Tabebuia, the overproduction of flowers probably increase the quality of their offsprings, by the abscission of the "poorest" seeded fruits.

The number of flowers leading to fruit is a result of the number of pollinated flowers, weather conditions, the level of intra - and interspecific competition for pollinators, the number of fertilized ovules, predation of fruit, and fruit maturation, which could act as a genetic sieve which favour pollen genotypes and offspring quality (Stephenson \& Bertin 1983, Stephenson \& Winsor 1986). Fruit maturation in many plant species has been pointed out as a pollinator limitation which reflects the shortage of pollinators or the lack of successful pollination (Schemske 1981, Bertin 1982, Aker 1982,
Waser 1983). It has been also regarded as result of sexual selection in which male genetic success is limited by its ability to reach the ovules, while female fitness is limited by the availability of resources for the egg (Janzen 1977, Willson 1979, Stenphenson \& Bertin 1983), the ultimate cause of fruit abortion (Janzen 1977, Stephenson 1981, Stephenson et al. 1985, Lee 1984). The production of surplus of flowers and the massive abscission as here documented in Tabebuia, suggest that the plants might have some control over their offsprings. Stephenson (1981), observed that Ceiba pentandra produces 1000 or more flower for each fruit, and Bertin (1982), showed that in Campsis radicans only $1-9 \%$ of flowers develop into fruits. In addition, Stephenson \& Winsor (1986), assumed that Lotus corniculatus aborted the fruits with fewest seeds improving the offsprings' quality. Recently, Henriques (1999), working with Oratea hexasperma, another cerrado species which blooms at the time as the Tabebuia, assumed that the low fruit production were caused by insufficient pollination, autogamous pollen deposition on the stigma surface and by the resource limitation of maternal parent.

Pollinators - It was frequently registered that the uppermost flowers of Tabebuia aurea and $T$. ochracea canopy were the first to be visited by the arriving bees (pers. observation). Both Tabebuia species were visited by the same spectrum of insects, comprising 14 species of bees (table 3 ). The visits started about 7:00 h, increase between 11:00 h to 14:00 h, and finished around 16:30 h, in both Tabebuia. Centris violacea, C. albopilosa and $C$. discolor, were the most frequent visitors, followed by Bombus morio, Eulaema nigrita, Epicharis bicolor, Trigona spinipes, Ceratina sp., Augochloropsis spp., and others. The first four species of bees were considered efficient pollinators because of their high frequency at Tabebuia flowers and also because they could easily contact the anthers and stigmas during flowers visits, which may not occur during flower visits of some of the other bees. Centris, Bombus, Eulaema and Epicharis, seemed to "recognize" Tabebuia flowers, for a long distance of the trees. These bees, mainly Centris and Bombus, arriving and entering very quickly (1-3 seconds) in the corollas making a strong sound. Many times, it was documented that the same bee, visited the same flower, more than once. All bees were more frequent visitors to $T$. aurea flowers than to those of 
T. ochracea. The species of Centris were also reported to be the principal pollinators of Tabebuia from Costa Rica, by Frankie et al (1983). In addition, SilberbauerGottsberger \& Gottsberger (1988), considered Centris, Bombus and Xylocopa as the main pollinators of the Bignoniaceae family. The males of Centris species and Trigona spinipes demonstrated aggressivity and many times seemed to deter foraging by some other bees. Trigona spinipes was the only bee observed perforating the corollas of mature buds, damaging pistils of T. aurea and T. ochracea and also perforating fruits of $T$. ochracea. The observed aggressive behaviour of male Centris, indicates that this bee is territorial and the male are not involved only in feeding activities, but also for searching females (Raw 1984). Such aggressive behaviour may have a useful role in pollination driving-off foraging bees from the canopy and converting geitonogamous visits to xenogamous ones. The activity of the stingless bee Trigona spinipes robbing nectar and piercing of the corollas of both Tabebuia, may also have a positive effect on fruit-set, because many potential pollinators will be forced to visit more flowers in order to get nectar which may increase cross pollination.

From data presented here, it can be concluded that Tabebuia aurea and T. ochracea are selfincompatible and non-apomitic species which rely on the same spectrum of bees for their pollination. It may be suggested that the species are involved in some kind of floral mutualism by the great amount of displayed flowers, which can be advantageous for both species by attracting large number of bees from greater distances and increasing chances of successful and progenies fitness.

Acknowledgements - Financial support was provided by grants from CNPq (Processo $n^{\circ}$ 291996/84). The author thanks to Dr. Peter Gibbs (University of St. Andrews, Scotland) for his assistance, to Dr. Linda Caldas (UnB) and Dr. Tarciso Filgueiras (UPIS) for critical suggestions on the manuscript, and to Dr. Anthony Raw (UnB) for insect identification.

\section{References}

AKER, C.L. 1982. Spatial and temporal dispersion patterns of pollination and their relationship to the flowering strategy of Yucca whipplei (Agavaceae). Oecologia $54: 243-252$.

ARMBRUSTER, W.S. 1986. Reproductive interaction between sympatric Dalechampia species: are natural assemblages "random" or organized? Ecology 67:522-533.
BARROS, M.A.G. 1992. Fenologia da floração, estratégias reprodutivas e polinização de espécies simpátricas do gênero Byrsonima Rich. (Malpighiaceae). Revista Brasileira de Biologia 52:343-353.

BARROS, M.A.G. 1996. Biologia reprodutiva e polinização de espécies simpátricas de Diplusodon (Lythraceae). Acta Botánica Mexicana 37:11-21.

BARROS, M.A.G. 1998. Sistemas reprodutivos e polinização em espécies simpátricas de Erythroxylum P. Br. (Erythroxylaceae). Revista Brasileira de Botânica 22:159166.

BARROWS, E.M. 1977. Floral maturation and insect visitors of Pachyptera hymenaea (Bignoniaceae). Biotropica 9:133-134.

BAWA, K.S. \& WEBB, C.J. 1984. Flower, fruit and seed abortion in tropical forest trees: implications, for the evolution of paternal and maternal reproductive patterns. American Journal of Botany 71:736-781.

BERTIN, R.I. 1982. Floral biology, hummingbird pollination and fruit production of trumpet creeper Campsis radicans (Bignoniaceae). American Journal of Botany 69:123134.

BERTIN, R.I. 1985. Nonrandom fruit production in Campsis radicans: between year consistency and effects of prior pollinations. American Naturalist 126:750-759.

BORRERO, J.I.H. 1972. Explotacion de las flores de Guayacan (Tabebuia chrysantha) por varias especies de aves e insetos. Biotropica 4:17-27.

EITEN, G. 1984. Vegetation of Brasilia. Phytocoelogia 12:271-272.

FRANKIE, G.W., HABER, W.A. \& BAWA, K.S. 1983. Characteristics and organization of the large bee pollination system in the Costa Rican dry forest. In Handbook of experimental pollination biology. (C.E. Jones \& R.J. Little, eds). Van Nostrand Reinhold Company, Inc. New York, p.411-448.

GENTRY, A.H. 1974a. Bignoniaceae in flora of Panama. Annals of the Missouri Botanical Garden 60:781-977.

GENTRY, A.H. 1974b. Flowering phenology and diversity in tropical Bignoniaceae. Biotropica 6:64-68.

GENTRY, A.H. 1974c. Coevolutionary patterns in Central American Bignoniaceae. Annals of the Missouri Botanical Garden 61:728-759.

GENTRY, A.H. 1976. Bignoniaceae in southern Central America: distribution and ecological specifity. Biotropica 8:117-131.

GENTRY, A.H. 1992. Bignoniaceae. Part II. Tribo Tecomae. Monografia $n^{\circ} 25$. Flora Neotropica. New York. p.126273.

GIBBS, P.E. \& BIANCHI, M. 1993. Post-pollination events in species of Chorisia (Bombacaceae) and Tabebuia (Bignoniaceae) with late acting self-incompatibility. Botanica Acta 106:64-71.

GOBATTO-RODRIGUES, A.A. \& STORT, M.N.S. 1992. Biologia floral e reprodução de Pyrostegia venusta (KerGrawl) Miers Bignoniaceae. Revista Brasileira de Botânica 15:1012-1031.

HENRIQUES, R.P.B. 1999. Ecologia da polinização de Ouratea hexasperma (St.Hil.) Bail (Ochanaceae) em cerrado no Brasil Central. Boletim do Herbário Ezechias Paulo Heringer 4:46-64. 
JANZEN, D. 1977. A note on optimal mate choice by plants. American Journal of Botany 1:365-371.

LEE, T. 1984. Patterns of fruit maturation: a gametophyte competition hypothesis. American Naturalist 123:427432.

MARTIN, F.W. 1959. Staining and observing pollen tubes in the style by means of fluorescence. Stain Technology $34: 125-128$.

McDADE, L. 1985. Breeding systems of Central American Aphelandra (Acanthaceae). American Journal of Botany 70:1515-1521.

OLIVEIRA, P.E., GIBBS, P.E., BARBOSA, A.A. \& TALAVERAS, S. 1992. Contrasting breeding systems in two Eriotheca (Bombacaceae) species of Brazilian cerrados. Plant Systematics and Evolution 179:207-219.

OLIVEIRA, P.E. \& GIBBS, P.E. 1994. Pollination biology and breeding systems of six Vochysia species. Journal of Tropical Ecology 10:509-522.

PROENÇA, C.E.B. \& GIBBS, P.E. 1994. Reproductive biology of eight sympatric Myrtaceae from Central Brazil. New Phytologist 126:343-354.

RAW, A. 1984. The nesting biology of nine species of Jamaican bees (Hymenoptera). Revista Brasileira de Entomologia 28:497-506.

SARAIVA, L.C., CEZAR, O. \& MONTEIRO, R. 1988. Biologia da polinizacão e sistemas de reprodução de Styrax camporum Pohl. e S. ferrugineus Nees et Mart. (Styracaceae). Revista Brasileira de Botânica 11:71-80.

SCHEMSKE, D. 1981. Floral convergence and pollinator sharing in two bee-pollinated tropical herbs. Ecology 62:946-954.

SEAVEY, S.R. \& BAWA, K.S. 1986. Late-acting selfincompatibility in Angiosperms. Botanical Review 52:196-215.

SILBERBAUER-GOTTSBERGER, I. \& GOTTSBERGER, G. 1988. A polinização de plantas de cerrado. Revista Brasileira de Biologia 48:651-663.
STEPHENSON, A.G.1981. Flower and fruit abortion proximate cause and ultimate functions. Annual Review of Ecology and Systematics 12:253-279.

STEPHENSON, A.G.M. \& BERTIN, R.J. 1983. Male competition female choice sexual selection in plants. In Pollination biology. (L. Real, ed.). Academic Press Incorporation, New York, p.109-149.

STEPHENSON, A.G., WINSOR, J. \& DAVIS, L. 1985. Effects of pollen load size in seed number, fruit maturation and seed quality in zucchini. In Biotechnology and ecology of pollen. (D.L. Mulcahy \& M. Ottaviano, eds.). SpringVerlag, New York, p.429-433.

STEPHENSON, A.G. \& WINSOR, J.A. 1986. Lotus corniculatus regulates offspring quality through selective fruit abortion. Evolution 40:453-458.

STILES, F.G. 1975. Ecology, flowering phenology and hummingbird pollination of some Costa Rican Heliconia species. Ecology 56:285-301.

STUCKY, J.M. 1985. Pollination systems of sympatric Ipomoea hederacea and I. purpurea and the significance of pollen flow. American Journal of Botany 72:32-43.

VIEIRA, M.F., MEIRA, R.M.S.A., QUEIROZ, L.P. \& MEIRA NETO, J.A.A. 1992. Polinização e reprodução de Jacaranda caroba (Vell.) D.C. (Bignoniaceae) em áreas de cerrado do sudoeste brasileiro. In Anais do $8^{\circ}$ Congresso da SBSP. São Paulo, Brasil, p.13-19.

VOGEL, S. \& MACHADO, I.C.S. 1991. Pollination of four sympatric species of Angelonia (Scrophulariaceae), by oil-collecting bees of NE Brazil. Plant Systematics and Evolution 178:153-178.

WASER, N.M. 1983. Competition for pollinator and floral character difference among sympatric plant species. A review of evidence. In Handbook of experimental pollination Biology. (C.E Jones \& R.J. Little, eds.). Van Nostrand Reinhold Company, Inc. New York, p.277-293.

WILLSON, M.F. 1979. Sexual selection in plants. American Journal of Botany 113:777-790. 